\title{
Effect of maternal exposure to nematode parasites in ewes on performance and parasite resistance in their lambs
}

J G M Houdijk, L A Jones, B J Tolkamp, S Athanasiadou, M R Hutchings

SAC, Edinburgh, United Kingdom

Email:jos.houdijk@sac.ac.uk

Introduction There is some evidence to suggest that exposure of ewes to parasites reduces weight gain in their lambs (Zaralis et al., 2008), although these effects are not observed when exposure is limited to late pregnancy only (Leyva et al., 1982). However, maternal exposure to parasites throughout pregnancy may affect off-spring performance and its resistance and resilience to parasites, as this may program offspring to better cope with parasite infections (Kristan, 2002). Here, we assessed effects of exposure of ewes to abomasal nematode parasites on ewe and lamb performance and on lamb resistance to the same parasites.

Materials and method Thirty-two 4-5 year old housed Mule ewes were either trickle infected with 10,000 Teladorsagia circumcincta infective larvae $(\mathrm{I}, \mathrm{n}=16)$ or sham infected with water $(\mathrm{C}, \mathrm{n}=16)$ from one week before synchronised mating with Suffolk rams until parturition $\left(\right.$ day $\left._{0}\right)$. Ewes weighed $(69.9 \pm 0.9 \mathrm{~kg})$ on day ${ }_{-158}$ and were commercially fed throughout. At scanning (day-88), 2 single-, 9 twin- and 1 triplet-bearing ewes were selected from each experimental group. Ewes were drenched at lambing to terminate the parasitic infection with Levacide (levimasole) and Oramec (ivermectin), and their lambs were trickle infected from day $_{38}$ until day ${ }_{77}$ with 2,000 T. circumcincta larvae. Lambs had access to creep feed from day $_{31}$ onwards and were weaned on day 66 . Ewes were weighed on day - $88_{\text {, }}$ and ewes and lambs were weekly weighed from lambing onwards. Ewe faecal egg counts (FEC, in eggs per gram, epg) were assessed during pregnancy to monitor the infection; lamb FEC were assessed twice weekly between day ${ }_{56}$ and day $_{77}$. FEC were transformed via $\log (\mathrm{FEC}+1)$ for statistical analyses, and reported as back-transformed means with a 95\% confidence intervals range. Obtained data were averaged per lamb reared, and were analysed using ANOVA, with ewe body weight at day-158 as covariate for ewe performance, lamb birth weight as covariate for lamb performance, and a repeated measure analysis for lamb FEC.

Results The number of barren ewes were similar in the C and I treatments (2/16 and 3/16, respectively). Mean FEC of I

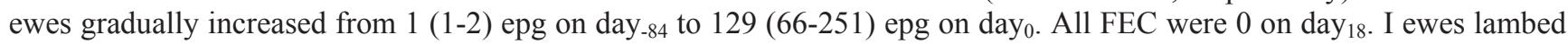
on average 1.4 days later than $\mathrm{C}$ ewes (s.e.d. $0.66 ; \mathrm{P}<0.05$ ), but reared similar number of lambs $(1.9 \pm 0.1)$. Table 1 shows that $\mathrm{I}$ ewes were lighter than $\mathrm{C}$ ewes during pregnancy and at parturition. This difference was smaller by day ${ }_{31}$ due to weight loss from $\mathrm{C}$ ewes, and disappeared by day ${ }_{66}$ due to a higher weight gain of I ewes. Ewe exposure to parasites did not affect mean lamb birth weight, but reduced lamb weight gain until day 38 and increased lamb weight gain during lamb exposure to parasites. Ewe exposure did not affect lamb FEC, which increased from 25 (22-29) to 242 (223-263) epg on day $_{62}$ and averaged $116(105-128)$ epg on day 77.

Table 1 Effect of maternal exposure to parasites on ewe and lamb performance and lamb faecal egg counts (FEC).

\begin{tabular}{|c|c|c|c|c|}
\hline & Control (C) & Infected (I) & s.e.d. & P-value \\
\hline \multicolumn{5}{|l|}{ Ewe body weight (kg) } \\
\hline day $_{-88}$ & 70.1 & 65.8 & 1.00 & $<0.001$ \\
\hline day $_{0}$ & 70.3 & 65.1 & 1.29 & $<0.001$ \\
\hline day $_{31}$ & 68.5 & 65.3 & 1.91 & 0.114 \\
\hline day $_{66}$ & 68.4 & 68.4 & 1.29 & 0.991 \\
\hline \multicolumn{5}{|l|}{ Ewe body weight gain (g/d) } \\
\hline $\operatorname{day}_{0-31}$ & -45 & 16 & 63.5 & 0.342 \\
\hline day $_{31-66}$ & 15 & 109 & 42.5 & 0.039 \\
\hline \multicolumn{5}{|l|}{ Lamb body weight (kg) } \\
\hline day $_{0}$ & 5.0 & 5.1 & 0.37 & 0.887 \\
\hline $\operatorname{day}_{38}$ & 19.7 & 18.2 & 0.60 & 0.020 \\
\hline day $_{73}$ & 35.3 & 35.2 & 1.15 & 0.923 \\
\hline \multicolumn{5}{|l|}{ Lamb body weight gain } \\
\hline (g/d) & 382 & 342 & 16.4 & 0.020 \\
\hline $\begin{array}{l}\text { day }_{0-38} \\
\text { day }_{38-77}\end{array}$ & 372 & 412 & 17.1 & 0.031 \\
\hline \multicolumn{5}{|l|}{ Lamb FEC $(\log (\operatorname{epg}+1))$} \\
\hline mean $\left(\right.$ day $\left._{56-77}\right)$ & 1.95 & 1.98 & 0.087 & 0.805 \\
\hline
\end{tabular}

Conclusion These data support the view that expression of immunity to parasites in immune ewes is nutritionally expensive and that body reserves may be sacrificed over reproductive effort to account for this. The reduced body reserves may be the basis for the reduced lamb weight gain observed during the immediately post lambing period. The data are consistent with the view that maternal exposure to nematode parasites may increases offspring resilience rather than resistance to infection with the same parasite.

\section{Acknowledgements}

SAC receives support from the Scottish Government, Rural and Environment Research and Analysis Directorate.

References Zaralis, K., Tolkamp, B.J., Houdijk, J.G.M, Wylie, A.R.G. and Kyriazakis, I. 2009. British Journal of Nutrition 101, 499-509.

Leyva, V., Henderson, A.E. and Sykes, A.R. 1982. Journal of Agricultural Science 99, 249-259.

Kristan, D.M. (2002). Journal of Experimental Biology 205, 3967-3977. 